\title{
The Implementation Of the Contract Financing Sharia Card PT. Bank Danamon of the Lawof $h$ is Reviewed From the Perspective of Fiqh Muamalah
}

\author{
Aliman Syahuri Zein ${ }^{1}$, Safrul Daulay ${ }^{2}$ \\ Email: 1alimansya@iain-padangsidimpuan.ac.id, ${ }^{2}$ safrulmantap88@gmail.com
}

${ }^{1}$ Institut Agama Islam Negeri Padangsidimpuan, ${ }^{2}$ Universitas Al-Wasliyah Medan

${ }^{1}$ Jl. H.T. Rizal Nurdin Km. 4,5 Sihitang, Padangsidimpuan

\begin{abstract}
Abstrak
Penelitian ini bertujuan untuk mengetahui implementasi akad pembiayaan kartu syariah pada PT. Bank Danamon Syariah jika dilihat dari perspektif fiqh muamalah. Penelitian ini menyimpulkan bahwa: 1) Dirham Card diluncurkan dengan mengacu pada fatwa Dewan Syariah Nasional Majelis Ulama Indonesia (DSN-MUI) No. 54/DSN-MUI/IX/2006 dan Surat Edaran Bank Indonesia No. 9/183 /DPbS/2007 tentang Persetujuan Kartu Danamon Syariah. 2), dalam pelaksanaannya, kartu Dirham menggunakan akad ijarah, sehingga pemegang kartu dikenakan biaya keanggotaan (cost of membership); akad Kafalah, karena penerbit kartu dapat menerima biaya (ujrah kafalah); dan akad Qardh, menyebabkan pemegang kartu wajib mengembalikan sejumlah dana yang ditarik pada waktunya. 3), beberapa ketentuan tentang biaya yang diwajibkan bagi calon pemegang kartu Dirham, yaitu penetapan besaran denda dan adanya kvisions dan btops (Dhawabith wa hudud). 4) terdapat beberapa ketentuan fikih muamalah yang belum jelas pada aplikasi Dirham Card, yaitu: (a) adanya inkonsistensi penggunaan istilah pada fatwa Islamic Card, istilah yang digunakan adalah akad Qardh namun pada ketentuan iuran pedagang, terdapat tagihan ujrah atau tahsil al-dayn, di satu sisi menggunakan istilah Qardh, sedangkan di sini. penggunaan lain dari istilah dayn; (b) kartu kredit syariah belum ada sistem kontrol yang dapat memastikan apakah pemegang kartu kredit yang menggunakan kartu kredit untuk membelanjakan barangnya halal saja atau sebaliknya; (c) kartu kredit syariah idealnya harus dapat menjamin penggunanya tidak israaf (konsumtif/berlebihan), sedangkan di sisi lain kartu kredit cenderung membuat pemegangnya menjadi konsumtif. Dalam hal ini jelas bertentangan dengan prinsip syariah; (d) adanya pungutan yaitu denda keterlambatan/denda dan adanya ta'wid (penggantian kerugian) yang disebabkan karena keterlambatan pembayaran. Hal ini tentu akan memunculkan pertanyaan apakah perbedaan pokok denda pada Kartu Syariah dan Kartu Kredit Konvensional.
\end{abstract}

Kata kunci: Kartu Syariah, Bank, Kafalah, Qard

\begin{abstract}
Research this aims to know the implementation of the contract financing sharia card on PT. Bank Danamon Syariah if viewed from the perspective of fiqh muamalah. The research is concluded that: 1) Dirham Card launched by referring to the National Sharia Board fatwa Majelis Ulama Indonesia (DSN-MUI) No. 54/DSN-MUI/IX/2006 and a Letter Circular of Bank Indonesia No. 9/183/DPbS/2007 on the approval of Danamon Syariah Card. 2) in the implementation Dirham card using akad Ijarah, so that the holder of the card charged membership fees (the cost of membership); akad Kafalah, cause the issuer of the card can receive a fee (ujrah kafalah); and the contract of Qard, cause the holder of the card is obliged to return by the amount of funds withdrawn in time. 3), some of the provisions about the fee that is required for prospective holder Dirham card, namely the determination of the amounts of the fines and the presence of kvisions and btops (Dhawabith wa hudud). 4), there
\end{abstract}


are some provisions fikih muamalah are not yet clear on the application Dirham Card, namely: (a) the presence of inconsistency in the use of the term on the fatwa of Islamic Card, the term that is used is the contract of Qard but on the provisions of the merchant fee, there are ujrah billing or tahsil al-dayn, on one side using the term Qard, while here. other uses of the term dayn; (b) card credit sharia there is no system of control which can make sure whether the holder of the card using the card 's credit to spend your items are halal course or vice versa; (c) card credit sharia ideally should be able to ensure users do not Israaf (consumptive/excessive), while in the side of another card credit tend to make the holder to be consumptive. In case this is clearly contrary to the principles of shariah; (d) the presence of charge i.e. late charge/fine and there ta'wid (replace loss) which is caused because of a delay in payment. It is certainly going to bring up the question of whether differences in the underlying fine in Sharia Card and Card Credit Conventional.

Keywords: Islamic Card, Bank, Kafalah, Qard

\section{Introduction}

In the era of globalization and digitization of the time here, industry financial increasingly develop, so too with the economic and financial sharia growing as quickly. The thing is, one of the only looks from the development of various products of the banking sharia and institutions financing sharia. One of the products referred to in the form of the availability of the cards of credit as a tool of payment. As the development of the times, the use of money as a tool of payment perceived the features of the obstacles. In addition to that, pe money in the amount of the big also provide the risk for penggunanya especially for those who have to do the transaction with the distance traveled that far. Barriers other also perceived when there is a need urgent that must be met. Some of the reasons that result in the reduced use to the money in cash, so there card plastic which is known by the term card of credit (credit card). Among the difference card credit with sharia card located at the use of flowers. Where, on the sharia card is not allowed to charge interest, but only for the services or fees of each transaction.

In Indonesia, card credit that is issued banking or institution financing of a conventional far more developed than the card credit sharia (islamic card) that is issued banking sharia or institution financing of sharia. Namun thus, the development of sharia card surely not be seen within the eyes of course, though not yet able to compensate for card of credit that is issued banking conventional. Se fundamental use card credit or sharia card can facilitate in the system of payment, earn money cash, goods, services or something that is worth the other and then pay 
for it in installments, as well as can be used as a tool of evidence or the best for a person in getting the loan according to the limit specified. (Ulul Azmi Mustafa, 2015)

But nevertheless, up to the time of this, only there are some bank syariah that apply or mengeluarkan produk syariah card this. Among them , PT. BNI Syariah and bank Danamon Syariah, whereas the National Sharia Council has issue the fatwa related to sharia card through the fatwa No:54/DSN-MUI/X/2006. As far as this according to the author, among the things that cause the least banking sharia issued a product from this is: Peration, yet can be used as a product featured because of the community of muslims as a share of the market 's largest banking islamic still have a view that considers the use of card credit conflicted with the system of sharia. Any one who caused it to lack of socialization and literacy about sharia card compared to the product of the banking sharia others. Second, from in terms of profits/earnings, it looks like the product is for banking sharia does not significantly affect the income than the products of financing another. Third, the existence of differences in the views of scholars about the law and the various transactions that occur in the islamic card, if viewed from the perspective of fiqh muamalah. Based on the description in the above, then the researchers are interested in conducting the study is more about "Implementasi Pembiayaan Syariah Card in PT. Bank Danamon Syariah Ditinjau Dari Perspective of Fiqh Muamalah”.

\section{Literature Review}

Card of credit in the language of Arab is called with the term "bithaqah i'timan", the dnatural context "Fikih Muamalah" is defined as "giving rights to others over his property with the bond of trust". Transactions such as this , according to scholars fikih is a transaction - free is not a transaction surrender the rights. For example it is said to someone, "please buy the items I this like you usual buy it from other people because I do not understand the price”. Maka people that buy it with the price of the ordinary he take out to buy the goods of a kind. In the world of business, it kind of is analogous to the loans, i.e. loans that are originated from the trust to the borrower because of the attitude of the mandate as well as his honesty. By reason of it, he gives a number of funds in the form of loans Fatwa of the National Sharia Council No:54/DSN-MUI/X/2006 to paid for delayed. (Firmanda, 2014) 


\section{The Implementation Of the Contract Financing Sharia Card \\ PT. Bank Danamon of the Lawof $h$ is Reviewed \\ From the Perspective of Fiqh Muamalah \\ Aliman Syahuri Zein dan Safrul Daulay}

The term "islamic card" much used by among academics and practitioners, among them there is a mention with the term "kartu kredit - based Sharia", "kartu kredit syariah", "Islamic Credit Card", or "kartu kredit based on prinsip syariah". Even the bank of sharia that has a product it also has a term that is diverse. For example "Dirham Card" used by bank Danamon Syariah, "Hasanah Card" used by the PT. BNI Syariah. While it is, of sharia card defines the sharia card is the "card which serves as card loans that have a relationship of law between the parties based on the principles of sharia”.

While it was, definition cards credit according to Article 1 Paragraph 4 of the Regulations of Bank Indonesia No. 14/2/PBI/2012 about the Changes to the Regulation of Bank Indonesia Number: 11/11/PBI/2009 concerning the Implementation of the Activities of the Tools of Payments with the Use of the Card (APMK) is tools of payments with the use of cards that can be used to perform a payment over the obligations that arise from the status of the activities of the economy,including the activities of purchase and/or to perform the withdrawal of cash, where the obligation of payment of the holder of the card is filled first advance by the issuer, and the holders of the card are obliged to do the payment on time that was agreed better with the repayment of it at once (charge card), or with payment in installments. (Bank Indonesia Regulation No. 14/2/PBI/2012, 2012)

Thus also, in the Regulation of the FSA Number/POJK.05/2014 Article 5 paragraph 2 are referred to with credit syariah (sharia card) is a tool of payments with the use of cards that can be used to perform a payment over the obligations that arise from an activity of the economy, including the transaction of purchase, where the obligation of payment of the holder of the card is filled first, first by the publisher (the acquirer), and the holder of the card is obliged to perform the payment obligations of the payment is on time that was agreed (either in direct or in installments). (the Financial Services Authority of the Republic of Indonesia, 2014)

Before the advent cards credit as a tool of payment in the transactions of the economy, transaction carried out by way of barter and then appears the money as an intermediary of exchange that is efficient and effective.(Cashmere, 2001) In essence istilah "syariah card" has a drawback because the cause ambiguity when interpreted based on the term. Se language, sharia card translated from "kartu syariah". Card syariah or syariah card according to practitioners can be meaningful area that is 
divided into 2 (two), namely card debit card finance (cards credit in the term conventional). So according to practitioners, the term card credit in Islam is more appropriate to use the term "kartu pembiayaan syariah" a Term that is almost similar also can be found in the book of Abdul Ghofur Anshori the use of the term "Card Financing Based on the Principles of Sharia.(Pujiono, 2005)

While that, the term "financing" can be interpreted as a funding that is given by one party to the party the other to support the investment that has been planned, well done alone or institutions. With other words, financing is financing that is issued to support the investment that has been planned. Financing also is a facility that given the bank's sharia to the people who need to use the funds that have been collected by the bank's sharia from the community that surplus funds. (Firmanda, 2014)

Based on the Law of Banking Syariah No. 21 Year 2008 contemplated by the Financing is the provision of funds or bills that are equated with it in the form of: transactions for the results in the form of mudharabah and musyarakah, transactions of lease in the form of ijarah or lease purchase in the form of ijarah muntahiya bittamlik, the transaction of sale and purchase in the form of accounts receivable murabaha, salam, and istishna', the transaction borrow borrow in the form of accounts receivable qardh; and the transaction of lease services in the form of bank to the transaction multiservice.(The Laws Of Islamic Banking No. 21 Of 2008)

As an explanation at the top, that between the difference card credit conventional with the sharia card is on the determination of the cost of interest and fees other (such as the cost of the fine delay) which arise on the month of such, will be accumulated with the rest of the debt of the principal which has not been paid after the date falling due, to calculate the cost of interest on the moon the next, so is known by the system flower flowering (flower that dibungakan back). In addition to that the calculation of interest on the kaertu credit also start determined based on the value of the initial debt at the time of the transaction and is based on the number of days the debt that goes. It was based on the balance of the debt of the average daily, which is calculated from the date of the transaction. While on sharia card using a system of calculation of the cost of the annual membership fee and the cost of monthly membership fee (the cost of the management of hdebt-ujrah the equivalent of 2.95\%). The amount is calculated based on the remaining debt of the principal clean 
after the date of the fall of the tempo. With thus, the cost of which arise in the months previous is not accumulated with the rest of the debt principal to calculate the cost on the moon next.(Firmanda, 2014)

\section{Terms The Marriage Contract In Islamic Card}

Between contracts used in islamic card, is:

a. Akad Kafalah, namely the contract that was used above warranties are given by the insurer (kafil) to the party third to meet the obligations of the parties of the second or a covered, which means maintaining or bear. Kafalah is a guarantee which is given by the insurer (kafil) to the party third to meet the obligations of the parties of the second or a covered, which means maintaining or bear the responsibility responsibility of another person as a guarantor.

b. Al-Qardh, is a treasure that is given or loaned by a person (the debtor) to another person, the loan is intended to help the parties to the borrower, and he must return it with nileai are the same. In the literature fikih classic, qardh categorized in aqd tathawwui or agreement of mutual help, and not the transaction is commercial. (Muhammad Syafi' Antonio, 2001)

c. Akad Ijarah, dnatural language Indonesian Ijarah can be interpreted as the wages. In the sense of broad, ijarah is a contract of transfer of rights to the above goods or services, through the payment of the above services that have been given, without followed by pemindahan ownership (ownership/milkiyyah) over the goods it's own.

While In the National Sharia Board Fatwa Majelis Ulama Indonesia (DSNMUI) No. 54/DSN-MUI/X/2006 regarding the sharia card there are a few considerations and provisions-provisions regarding use of the card credit sharia (Syariah Card) as follows:

a. The activities of the economy that is increasingly global and global and complex requires an instrument practical to carry the transaction, by the due it its ease of bermuamalat is the needs of people who need to respond with the positive.

b. Card credit that there is now run and operated not in accordance with the shari'ah of islam because of the using the principle of interest. 
c. Need to include instruments replacement of card credit conventional that not berprinsipkan interest as a product of an alternative which is safe and reassuring. (National Sharia Board of the Indonesian ulema council, 2006)

\section{Methods}

Research this is the type of research is qualitative descriptive (exploratory). Research qualitative is research that intends to understand the phenomenon of what that is experienced by the subject of the research. (Moleong, 2013) While it, that referred to ptudy descriptive namely research that raised a fact, variables and phenomena that occur while now (when the research took place). (Sudarajat, 2001) In terms of this, researchers want to do analysis about the implementation of sharia card in Bank Danamon Syariah reviewed from the perspective of fiqh muamalah, so find a bright how to practice sharia card if it is associated with the fatwa DSN/MUI, 2006.

\section{Results and Discussion}

Based on the National Sharia Board Fatwa Majelis Ulama Indonesia (DSNMUI) No. 54/DSN-MUI/X/2006 about the provisions of the sharia card mention some of the conditions that must be met as follows :(National Sharia Board of the Indonesian ulema council, 2006)

\section{Terms Contract}

1. Akad Kafalah, used by penerbit kartu as guarantor (kafil) for pemegang kartu against the merchant top of all the obligations to pay (dayn), as a result of the transaction between the pemegang kartu with the merchant, and/or the withdrawal of cash from in addition to the bank or ATM bank penerbit kartu. With such, the publisher of the card is allowed to receive a fee (ujrah of kafalah).

2. Contract of Qard, used by penerbit kartu is the giver of the loan (muqridh) to pemegang kartu (muqtaridh) through the withdrawal of cash from bank or ATM bank penerbit kartu

3. Akad Ijarah, used by penerbit kartu as a provider of services the system of payments and services to the pemegang kartu. By because of it, pemegang kartu charged a membership fee. 


\section{Terms Fee}

1. Dues membership (membership fee) as penerbit kartu entitled to receive dues membership (rusum al-'udhwiyah) including the extension of the membership of the holder of the Card as a reward (ujrah) above permits the use of the facilities of the card.

2. Merchant fee penerbit kartu may receive a fee that is taken from the price of the object of the transaction or services as wages/rewards (ujrah) upper intermediate (samsarah), marketing (taswiq) and billing (tahsil al-dayn).

3. Fee upon withdrawal of money cash penerbit card may receive a fee withdrawal money cash (rusum sahb al-nuqud) as a fee the above services and use of facilities that magnitude is not associated with the amount of the withdrawal.

\section{Terms Ta'widh and Fines}

1. Ta'widh top penerbit kartu can wear ta'widh, i.e. replace the loss against the costs that are incurred by penerbit kartu due to delay voting card in paying its obligations which have fallen due.

2. Fine delay (late charge) over penerbit card can be put on a fine late payments which will be recognized entirely as a fund social.

\section{Dirham Card PT. Bank Danamon Syariah}

In principle Dirham Card published to meet the needs of the muslims of the modern top of the transaction card of credit that is based on sharia. Dirham Card is a card pay (payment card) that can be used for payment upon the purchase of a number of goods funds services are lawful and not contrary to the principles of sharia with the merchant (the party of the third). Customer Dirham Card given freedom to pay, either in full or in installments.

Dirham Card launched by referring to the National Sharia Board fatwa Majelis Ulama Indonesia (DSN-MUI) No. 54/DSN-MUI/IX/2006 and Bank Indonesia Circular Letter No. 9/183/DPbS/2007 on the approval of Danamon Syariah Card. Some of the considerations that are taken in the launch of the card is, including: First, the global and the complexity of the transactions that are needed by the actors of the economy, so it requires an instrument that is easy and practical, but still 
according to the principles of sharia; the Second, the number of the product card credit that offered banking conventional with the use of flowers.

By because it is, to facilitate transactions for the ummah of Islam, PT. Bank Danamon Syariah has been trying to launch Dirham Card. Dirham Card is a card credit sharia is the first in Indonesia to offer a unique, functionality and a variety of profit but still have to meet the provisions of sharia. Launch Dirham Card aims to complement the series of products are offered to the customers of Bank Danamon. One of the factors that affect the improvement of the position of bank Danamon from rank 6 to be rank 12, dnature some years past, is the position of bank Danamon as the bank is the issuer of the card the largest in Indonesia. (Rahmawati et al., 2011)

Some kdetached building has an advantage that is offered by Dirhams Card among others:

1. Do not use the system of interest, but the system cost of the lease based on the principle of ijarah

2. The determination of the price (pricing) quite competitive so that it is fair because applying the calculation of the fee

3. The management of the funds of virtue (qardhul hasan) are obtained from the implementation of the product card sharia; for example, late payment fee, channeled to the activities of the social.

4. There is a benefit or the benefit base, (for example the presence of a discount for bills of electricity, telephone, water and TV cable) in a number of the merchant.

5. Allows the use of cards for purposes which are spiritual, such as the umrah or both spiritual.

6. Accepted in all network Master Card in the whole world

\section{Implementation Dirham Card}

In general, the implementation Dirham Card at bank Danamon Syariah can be described through the scheme following this. 
The Implementation Of the Contract Financing Sharia Card

PT. Bank Danamon of the Lawof $h$ is Reviewed

From the Perspective of Fiqh Muamalah

Aliman Syahuri Zein dan Safrul Daulay

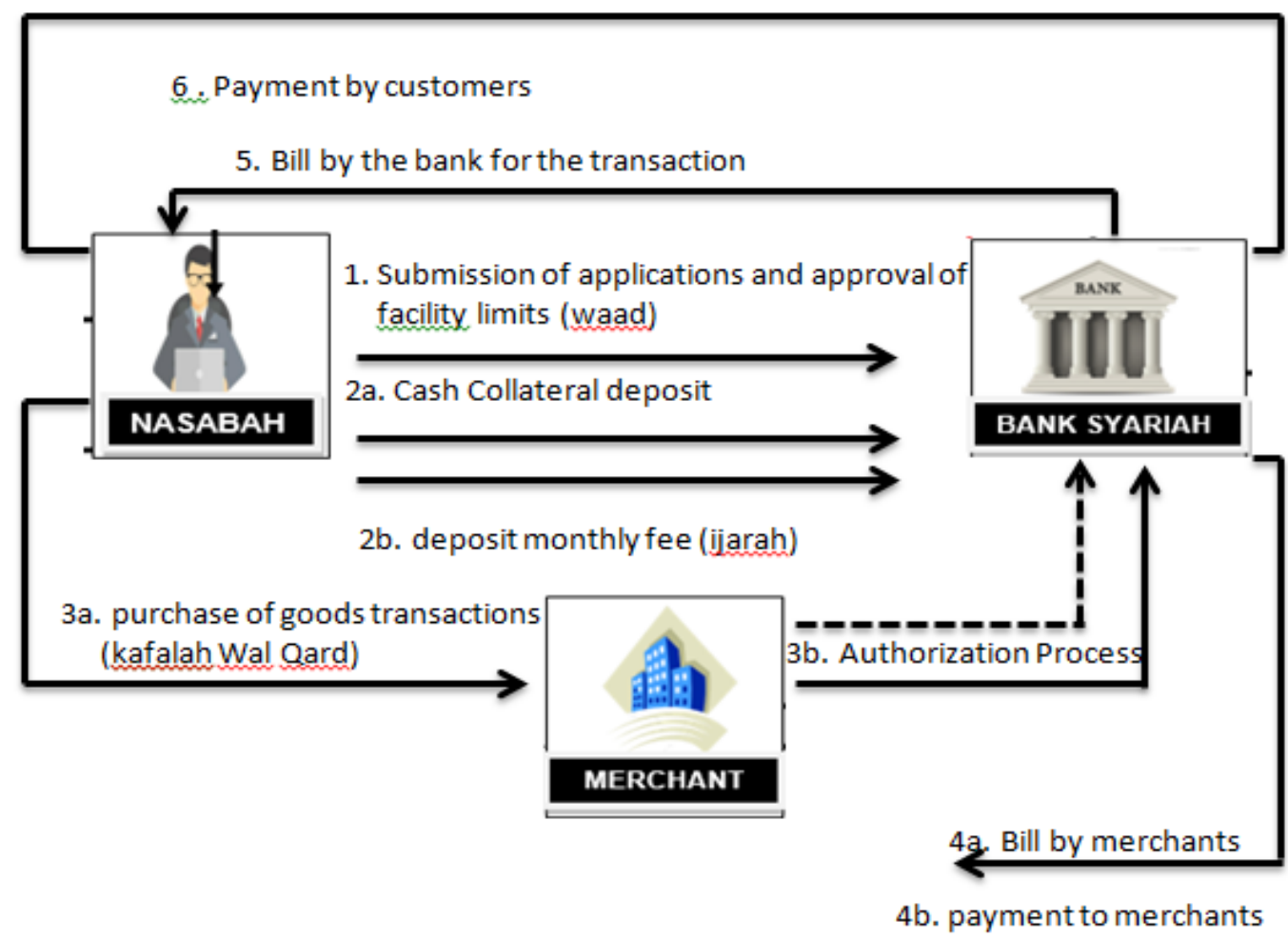

Based on the scheme in the above, it can be explained that the implementation Dirham card using the contract;

1. Akad Ijarah,

$\mathrm{Al}$ Ijarah is derived from the word Al-Ajru that means $\mathrm{Al}$ 'Iwadhu (replace). According to the understanding of personality', $\mathrm{Al}$ Ijarah is a type of contract to take benefits with the path of the turn. (Sayyid Sabiq, 1987) On a contract or scheme of the transaction bank, the issuer of the card is the provider of the payment systems and services to the card holder. Over the provision of services or ijarah such, the cardholder charged a membership fee (the cost of membership).

2. Akad Kafalah

In the Language of kafalah means adh-dhammu (combine). Kafalah is also called dhaman (the best), hamalah (load), and za'amah (dependents). Expert in fiqh Hanafi school defines that the kafalah is the process of merging dependents. (Sayyid Sabiq, 1987) In terms dirham card issuer of the card is the guarantor (kafil) for the cardholder against the merchant for all obligations to pay (dayn) that arise from a transaction between the cardholder and the merchant, and / or withdrawal of cash from in addition to the bank or the ATM 
of the issuing bank. Of the giving of the guarantee, the issuer of the card can receive a fee (ujrah kafalah).

3. Contract Of Qard

$\mathrm{Al}$ Qard is giving the treasure to the people of other that can be charged or requested return or with the word other to lend without expecting anything in return. In the literature of fiqh classic, qard categorized in contract tathawwu or mutual help and not commercial transactions. (Heri Sudarsono, 2003) For the contract of qard on the dirham card, the card issuer is the lender to the card holder through the withdrawal of cash from the bank or the ATM of the issuing bank of the card. Card holder thus obliged to return the amount of funds withdrawn in time.

As far as this, based on some of literature that are available, there are several provisions about the fee required for prospective card holders, namely:

1. Membership fee (rusum al-'udhwiyah), is membership dues, including the extension of the membership of the holder of the card as a rewards permission top use of the facilities of the card;

2. The Merchant fee, is a fee that is taken from the price of the object of the transaction or the services as the wage/compensation (ujrah samsarah), marketing (taswiq), and billing (tahsil al-dayn)

3. Fee for cash withdrawal (sahb al-naqdi), is a fee for the use of facilities for the withdrawal of cash (Rusum Shahib al Nuqud) the amount of which was not associated with the amount of the withdrawal that is made.

4. Fee kafalah, is a fee given the card holder for the provision of kafalah.

While that, the customers also have to pay a tha, in the form of:

1. Fine delay (late charge), is a fine due to delay in payment of which is recognized as a fund social;

2. Fines for exceeding the ceiling (ceiling over limit charge) is the fines imposed because beyond the limit that is given.

While the kvisions and btops (Dhawabith wa hudud) in Dirhams Card, namely:

1. Funds received to be used for things that usury;

2. The funds received are not used for the transaction object that is unlawful or 
The Implementation Of the Contract Financing Sharia Card

PT. Bank Danamon of the Lawof $h$ is Reviewed

From the Perspective of Fiqh Muamalah

Aliman Syahuri Zein dan Safrul Daulay

immoral

3. Funds received to push for spending an excessive (israaf)

4. Funds received tidak raises the debt that doubled so be ballast in pay off his debts (ghalabah al dain)

5. The holder of the card key should have the capability financial to pay off the financing on time

6. Funds received tidak used to provide services that conflict with Sharia

\section{Findings Research}

For banking sharia, especially for PT. Danamon Syariah presence of the islamic card to be a proof of the form of service to the customer who want to acquire ease in a variety of transactions. But nevertheless, pro-cons to the product is also still there, although its appearance has been supported by a fatwa DSN MUI about sharia card. So far this if viewed from the perspective of fiqh muamalah, then some of the problems that arise from the product syariah card among others; the first, adanya lack of consistency in the use of the term on the fatwa of Islamic Card, the term that is used is the contract of Qard but on the provisions of the merchant fee , there are ujrah billing or tahsil al-dayn, on one side using the term Qard, while here. other uses of the term dayn. Pdifferences are very thin, this, of course can cause implications are quite extensive. Qardul hasan actually is the contract that are working together in the form of aid money bercondong its use for business (productive). It is different with Dayn (debt) that its use is bersifat consumptive, and it is in the automatic different contract. By because it is, in Islam recommends to use the system work the same (Obvious) of the system Dayn (debt).

Second, kartu credit sharia there is no system of control which can make sure whether the holder of the card using the card 's credit to spend your items are halal course or vice versa, because during this, when a customer uses a card credit both islamic and conventional to transactions with how to swipe it away, then that is recorded is the name of the merchant is not the name of the item goods are purchased. It is make card credit sharia in the use of vulnerable happened fraud. Then of course need to include something that can eliminate the harm is, it is in accordance with the rules of the quran which reads: الضرر يزال Means: "Kemadharatan it should be eliminated." In the case that concerns the harm is then supposed to be on 
sharia card this should be no loss of trustees, which is a systemic can minimize the presence of misappropriation usage cards credit sharia, so that the harm that occurs can be eliminated.

Third, kartu credit sharia ideally should be able to make sure users don't Israf (consumptive/excessive), while in the side of another card credit tend to make the holder to be consumptive. In case this is clearly contrary to the principles of sharia. But on the level of practice to the-Israf-an, this can be minimized with the presence of the ceiling limit based on the type of card, that card green, card gold, and cards platinum. But need to realize that adanya ceiling limit is not as well as immediately giving the disappearance of harm, in case it is corrupt Israf, so that the Israf will still occur despite the presence of the ceiling limit. A creation of the product diperbankan sharia should be based on the objective product was created that prevent from riba, gharar, However, or konsumsi that excessive, exploitation, and so on. If seen aspects of the purpose of the existence of a product then there is a match the rules of the quran which say: ألهور بمقاصدها That: "Each case (the deeds) that depends on the goal."

Fourth, adanya charge that late charge/fine and there ta'wid (replace loss) which is caused because of a delay in payment. It is certainly going to bring up the question of whether differences in the underlying fine in Sharia Card and Card Credit Conventional. While it is, the imposition of ta"wid by bank syariah is also the cause of controversy among scholars. According to the ijtihad Kamal Hammad, only the supreme court who is authorized to give punishment to the customer defaul payment. He refused a penalty against the customer defaul payment with compensation. While ijtihad scientific Syaykh Mustafa al-Zarqa", as quoted Mohammad Ali Elgari et.al, argue that the penalty of fines should be decided by the court of the high course and the money fines that only can be utilized for the benefit of social. Bank Syari"ah don 't take the money fines that, but all the money fines that must be used to maslahah 'ammah (public interest).(Kholis, n.d.)

While ijtihad scientific collective Islamic Fiqh Academy, issued a fatwa that if the customer fails to pay the installments on time that has been agreed upon, then the bank's sharia not be wearing a fine or paid other over the failure of the, because it is the same course with applying the concept of interest on installments. (Kholis, n.d.) While according to al-Sadiq al-Darir argue fines against the defaul payment with terms of the amount of a fine that does not exceed the amount of debt the customer is 
allowed. Muhammad Taqi Usmani support the opinion is, that the customer defaul payment or ta"wid should pay all the money to the institutions of the social which is owned bank syariah. While it, Bank syariah won 't get the slightest of money fines that. So the money is fine it is not a compensation over the financing of a given bank syariah as the opportunity cost. While Umer Chapra and Tariqullah Khan stated that if defaul payment is not subject to a penalty or a fine, then it 's going to be the one example that is not good for the continuity of economic, social, and people who defaul payment that will continue to constantly perform dishonesty.

By because of it, Umer Chapra and Khan proposed the concept of "Loss Given Default" (LGD) to determine the amount of compensation that can be subtracting the values of injustice between the parties, customer and bank syariah moment happened defaul payment with terms of the amount of compensation already approved by the clergy, in the case of this example the National Sharia Council.

While according to Joni obedience has bin Borhan argue, that the imposition of a change of loss (ta'wid mali) according to some expert economy of Islam is allowed with argument-argument the following: (1) In between the core of the law of Islam is the concept of "rejection madarat" in which each madarat or losses should be avoided. (2) the Practice of riba only occur in case of exchange the money with the money or goods of the borrower. with the goods of the borrower.. In the case of the imposition of mercenaries replace the loss, he charged to the top of the failure of the customer in the contract exchange (mu'awadah) that involves an exchange between currencies with the goods, namely of the type and properties are different. In terms of this there ijtihad fikih since the bay' al-'arbun and the permissibility of forfeiture of the deposit money due to replace the losses of the seller to wait and not market the stuff that gets booked it to the customer other. The losses in the case of bay' al-'arbun is shaped harm the economy, while losses are borne by investors and savers by defaul payment is shaped loss real. (3) Usury always give an excess of one of the parties to the above parties to the other, while mercenaries replace the loss only just restore the state of the losses to the state of no loss. This does not benefit the parties of the bank, for the purpose of change and loss only just fix the state.

For the problem of Sharia Card is then the opinion of taken the opinion of Umar Chapra and Thariqul Khan. Should no agreement ta"wid that injustice can be eliminated. This is in accordance with the rules of jurisprudence that artinya: 
"Kemadharatan that is large/ heavy eliminated with Kemadharatan that is light." The harm that is great is the presence of ta"wid that burdensome on any one party, while the holding of deliberation in the determination of ta'wid so is not harming any one party. Second, the presence of Islamic Card with using contract services (services) services need to include prudence so as not to get in the circle rules in terms of this is the prohibition of riba. The emergence of various polemics between the other on the selection of the contract, because the contract that was used is a contract of Qard or financing then required the presence of collateral. Contract of Qard it literally is the contract with the principle of lending and borrowing for non-business that must be accompanied by the best. Qard is giving the treasure to other people who can be charged or requested back or with other words lend without no expectations in return. In the literature of jurisprudence classic qard categorized in contract tathowwui or agreement of mutual help , and not be commercial. (Abdul Aziz and Maria Ulfah, 2010) With a contract of Qard, holder card credit sharia should deposit the deposit into the collateral at once limit the credit. The Deposit is stored in the form of deposits and savings that won 't be drawn, it also becomes the identity of the presence of goodwill invesment of the customer 's own. Akad Qord allows the holder of the card to repay the money. In here we can see the presence of a paradox in the side of the other people that are into card credit sharia is the people who wish to owe but on the other precisely have to have the money first as a form of deposit.

\section{Conclusion}

Based on the discussion and findings of the research, then some conclusions of the research on this is as follows: first, dirham Card launched by referring to the National Sharia Board fatwa Majelis Ulama Indonesia (DSN-MUI) No. 54/DSNMUI/IX/2006 and a Letter Circular of Bank Indonesia No. 9/183/DPbS/2007 on the approval of Danamon Syariah Card. Second, in the implementation Dirham card using akad Ijarah, so that the holder of the card charged membership fees (the cost of membership); akad Kafalah, cause the issuer of the card can receive a fee (ujrah kafalah); and the contract of Qard, cause the holder of the card is obliged to return by the amount of funds withdrawn in time. Third, Some of the provisions about the fee that is required for prospective holder dirham card, namely the determination of the 
The Implementation Of the Contract Financing Sharia Card

PT. Bank Danamon of the Lawof $h$ is Reviewed

From the Perspective of Fiqh Muamalah

Aliman Syahuri Zein dan Safrul Daulay

amounts of the fines and the presence of kvisions and btops (Dhawabith wa hudud). Fourth, there are some provisions fikih muamalah are not yet clear on the application Dirham Card, namely: (1) the presence of inconsistency in the use of the term on the fatwa of Islamic Card, the term that is used is the contract of Qard but on the provisions of the merchant fee, there are ujrah billing or tahsil al-dayn, on one side using the term Qard, while here. other uses of the term dayn; (2) card credit sharia there is no system of control which can make sure whether the holder of the card using the card 's credit to spend your items are halal course or vice versa; (3) card credit sharia ideally should be able to ensure users do not Israaf (consumptive/excessive), while in the side of another card credit tend to make the holder to be consumptive. In case this is clearly contrary to the principles of shariah; (4) the presence of charge i.e. late charge/fine and there ta'wid (replace loss) which is caused because of a delay in payment. It is certainly going to bring up the question of whether differences in the underlying fine in Sharia Card and Card Credit Conventional.

\section{References}

Abdul Aziz and Maria Ulfah. (2010). Capita Selecta Economics Contemporary Islam. Alfabeta.

National Sharia board of the Indonesian ulema council, H. fatwa D.-M. (2006). The National Sharia Board Fatwa Majelis Ulama Indonesia (DSN-MUI) No. 54/DSNMUI/X/2006. CV Gaung Persada.

FIRMANDA, H. (2014). Syariâah Card (Credit Card Sharia) In Terms Of The Principle Of Utility And Maslahah. Journal Of The Science Of Law Riau, 4(2), 9163.

Heri Sudarsono. (2003). Banks and Islamic Financial Institutions. EKONISIA Kampes Faculty of Economics, universitas islam indonesia.

Cashmere. (2001). Banks and Other Financial Institutions. Rajawali Press.

Kholis, N. (n.d.). The Urgency Of Ijtihad Scientific In Answer To The Problems Of Legal Transaction Contemporary. Papers. The E book.

Meleong, L. J. (2013). Qualitative Research Methods. PT remaja Rosdakarya.

Muhammad Syafi' Antonio. (2001). Islamic Banks From Theory To Practice. Gema Insani. 
The Financial Services Authority Of The Republic Of Indonesia. (2014). The Financial Services Authority regulation No. 31/POJK.05/2014 On The Implementation Of Islamic Finance. The Financial Services Authority Regulation, 18, 27-38. http://www.ojk.go.id

Bank Indonesia regulation No. 14/2/PBI/2012, (2012).

Pujiono, A. (2005). Islamic Credit Card (A Study Of The System Of Payment Of Contemporary Islam). Journal Of The Dynamics Of Development, No. 1 Vol., 66.

Sayyid Sabiq. (1987). Fikih Sunnah Of 13. PT Al ma'arif.

Tbsp, K., West, B., \& Dan, S. (2011). The Concentration Of Sharia Banking Study Program Muamalat ( Islamic Economics ) Universitas Islam Negeri 2011 M / $1432 \mathrm{H}$.

Sudarajat, S. and. (2001). Basic Scientific Research (Mold 1). Pustaka Setia.

Ulul Azmi Gus. (2015). Sharia Card The Perspective Of Al-Maqasid Syariah. Scientific Journal Of Islamic Economics, 01(01), 17-28.

The Law Of Islamic Banking No. 21 Year 2008, (2008). 